\title{
EFFECTS OF THE GLOBAL FINANCIAL CRISIS IN THE BANKING SYSTEM OF KOSOVO
}

\section{Myrvete Badivuku-Pantina ${ }^{1}$ Anera Alishani}

Faculty of Economy, University of Pristina

Iliria University

Received: 12.08 .2012

Accepted: 30.08.2012
Original scientific paper

\begin{abstract}
Financial crises are phenomena that happened before and continue to happen even nowadays. There were many financial crises in the last century, starting with the Great Depression of 1929 and continuing with other financial crisis, and it was believed that people would learn from their previous experiences and would not allow the crisis to happen again. But the financial crisis of 2007, created the impression that no one wanted to learn for the real causes of their occurrence and consequences, often disastrous for countries and the globe, and as such allowed the crisis to be repeated.

Effects of the 2007 financial crisis, which originally started in the USA's mortgage market and which was quickly spread all over the world, even to this date it still continues to have effect on real economies of many states, e.g. Greece. The spread of the crisis was primarily due to globalization and commercial trades among countries. Because of the dependence of economies on one another it was created the domino effect and all the countries were affected from the crisis. As a result, the crisis seems to have revealed the disadvantages of globalization. Finances of the world were shocked and rapid fluctuations were reflected in the stock prices.

Kosovo, as a new and small country in the Western Balkans is not much globalized and open which was beneficial in preventing it from being affected from the global financial crisis. Its economy has slightly felt the effect of the crisis because the banking system in Kosovo is not much open to the international financial markets as they operate mostly with their clients' deposits.

The purpose of this research is to assess the implications of the global financial crisis in the banking system of Kosovo, and also to identify the measures that the Central Bank and the Government should undertake in order to protect the economy from external implications.
\end{abstract}

Key words: Financial crises, Kosovo's economy, banking system, effects

\footnotetext{
${ }^{1}$ Correspodence to:

Myrvete Badivuku-Pantina, Faculty of Economy, University of Pristina Rr. "Agim Ramadani" p.n. 10 000, Pristina, Kosovo

Phone: +381(0)38221 895/ 228966

E-mail: myrvete.badivuku@uni-pr.edu
} 
THE RECENT GLOBAL FINANCIAL CRISIS

The financial crises continue to remain unsolved phenomena even nowadays. The number of crises rises every day, while the factors that are causing the crises can be different; economic, political, social, climatic, financial, etc. However, it is evident that today because of globalization, the effects of the crisis can spread quickly around the world, due to financial and trade co-operations among the states.

According to Romer (2003), since the Great Depression of 1929, one of the severest crisis of the last century, the world has faced many other crises such as; the oil crisis of 1973, the "Black Monday" of 1987, Russian crisis of 1998, and many other crisis but the crises of 2007 is one of the largest, consequences of which are felt even today.

The recent crisis begun in the American's banking system which soon turned into the deepest recession in the history of the U.S.A and ended as the economic crisis in global level (Gaggi, 2009). This crisis led to the increase of the unemployment rates to their highest levels in the last thirty years, to the deep declines of stock markets, while the fall of the customers' demand made the positive trends of economic growth to turn negative and to decline massively in many states of the world. More specifically, according to the report of International Monetary Fund (2009) in industrialized economies the real GDP growth rate fell from $2.7 \%$ in 2007 to $-3.8 \%$ in 2009 , in developing countries it fell from $10.6 \%$ to $4.8 \%$, and in developed countries it fell from 5.4\% to $-3.7 \%$ for 2007 and 2009, respectively.

The overall losses, officially recorded and which were as a result of the global crisis, reached up to 969 billion dollars. The International Monetary Fund foresees that the official losses to be recorded will grew up to 1.4 trillion dollars as the crisis has not ended yet.

Even though there have not been any significant signs that Kosovo is overtaken from the financial crisis, the possibility that it may suffer in the future should be taken into consideration, as most of the
European countries already are involved in deep debt problems due to the global financial crisis. The country's economic experts emphasize that Kosovo is in crisis already, because Kosovo's economy is fragile with a high level of imports while exports cover the imports with only $10-12 \%$, but the effects are modest. On the other hand, the Central Bank of Kosovo (CBK) is limited in its powers as it uses as its currency the Euro, which make the Central Bank of Kosovo be very dependent and unable to manipulate with monetary policies. According to the Financial Stability Report of the Central Bank of the Republic of Kosovo ( $\mathrm{nr} 2,2011)$, it can be suggested that the effect of global financial crisis in Kosovo's financial sector were lower in comparison to neighbouring countries e.g. Greece. The situation in Kosovo was characterized by a low degree of credit crunch, and declines in remittances and Foreign Direct Investments (FDI) but it could maintain sustainability in its financial sector because in not exposed much to foreign bank capital (banks work more with deposits of the clients rather than foreign lending according to the Annual Reports of the Central Bank of Kosovo for the years 2009 and 2010).

\section{THE BEGINNING OF THE GLOBAL FINAN- CIAL CRISIS}

The global financial and economic system was involved in trouble and uncertainty during the years of 2007-2008. This crisis was due to high level of globalization and financial integration that all countries have among each other nowadays. In the first phase, according to Cooper (2008), the crisis touched the financial markets of the most developed countries in the world. While the second phase was characterized more by a significant impact of the crisis on the real economic indicators in both developed and developing countries, including also poor countries.

The financial crisis began in the second half of the year 2006 with the decline of the returns on mortgage debts (subprime) in U.S.A. which made many debtors incapable of repaying their debts. 
This crisis, also referred as 'subprime mortgage meltdown', is a crisis that affected severely the mortgage sector in the U.S.A and is considered to be the main factor of the international financial crisis of the years 2007-2008 (Bitner, 2008). This crisis emerged through real estate loans (or mortgage) with high risk in the U.S.A also called as "sub-primes", holders of which were mainly the people with poor or unstable incomes and unable to repay them (Paulson, 2007).

In February of 2007 the crisis was spread to banking sector by becoming now as financial crisis which included the largest mortgage lenders and investment banks. This crisis caused the stock market to collapse in the summer of 2007. State authorities and financial experts suggested that the crisis was more due to the lack of interbank liquidity, and as such they reacted by introduc- ing monetary amounts in the interbank market. But the crisis rapidly turned into crisis of banking and financial insolvency (Ruth, 2008). This situation caused the growth of interbank liquidity crisis, growth of the crisis of mutual integrity and increase in the interest rate of interbank debts. The financial crisis reached its peak in September 2008, where many American financial institutions were in a situation of bankruptcy or were rescued by the intervention of the FED (Boissieu, 2008). Thus, the crisis turned from the U.S. financial crisis into the financial and banking crisis in other developed countries. GDP fell drastically and many businesses reduced the workplaces causing the unemployment rates to rise. According to the figure below, also the GDP growth declined drastically in U.S.A, Canada, and some other countries of the EU.

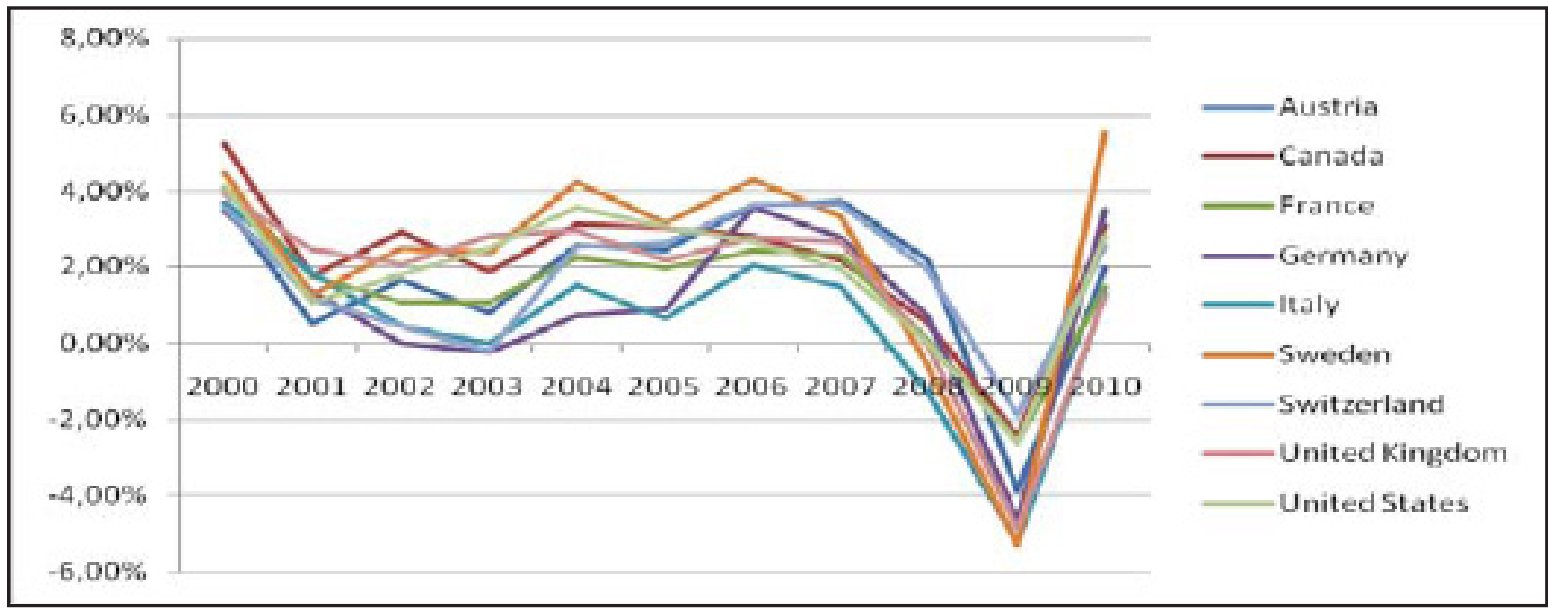

Figure 1.GDP Growth in USA, Canada, and some other countries in EU (20002010(International Monetary Fund, 2010)

Given that the countries were sinking into deep financial problems, the governments tried to buy as much as possible illiquid assets to make the lending possible again. On the other hand, the Central Banks tried to reduce the interest rates, but because the interest rates were already very low (they already were down to $1 \%$ based on the decision of FED) as a result there was no way to be rescued from the crisis. In 2008, the Europe was officially in recession. 
THE PERFORMANCE OF THE BANKING SECTOR AND THE ECONOMY OF KOSOVO

Although in the years of post-war Kosovo has seen economic growth, it still remains as one of the most underdeveloped country in the Europe. According to the Annual Reports of the Central Bank of Kosovo, in 2009, Kosovo's economy recorded a real GDP growth of $4.0 \%$, while in 2010 the GDP growth was $4.6 \%$ which in nominal terms was 4.2 billion Euros. This economic growth during the last years was generated from the growth of both private consumptions and public investments, which were mainly financed from the loans of banking sector, remittances, substantial growth of public spending, and also from the foreign assistance. However, the economic growth of 2010 was primarily as a result of private sector contribution, namely consumption and investment in this sector, while in 2009 the GDP growth was due to the public sector. The year of 2010 is characterized also by an increase in general consumption for $3.3 \%(0.9 \%$ in 2009), influenced by an increase in the consumption of private and public sector. Also investments grew in 2010, this increase was $7.8 \%$, but was 2 percentage points slower than in 2009 (9.8\% in 2009).
While in 2009 Kosovo's economy was characterized with deflation (-2.4\%), during the 2010 the inflation rates rose when the consumer price index reached 3.5\%. According to Haderi et al. (1999) the high dependence of the economy on imports also affected the price movements in Kosovo, so inflationary pressures on the global level during 2010 made the economy of Kosovo to have increased inflation (increased prices of food products, oil derivatives).

Labour market is in deep problems, where the unemployment rate reached up to $45 \%$ (Statistical Office in Kosovo, 2010), and continues to be a challenge for the economy of Kosovo. Based on the data from the Ministry of Labour and Social Welfare (MLSW), during 2004-2010, on average 30,000 people per year were registered as new jobseekers, while the average number of new job places for one year was about 7,500. It is suggested that $80 \%$ of employees in Kosovo are employed in the private sector, while in the public sector which is considered as an important employer, work the remaining $(20 \%)$ of the total number of employees in the country (MLSW).

The effects of the global financial crisis were felt indirectly in the economy of Kosovo.

Table 1. The most important macroeconomic indicators for Kosovo, 2006-2010

\begin{tabular}{lrrrrr}
\hline \multicolumn{1}{c}{ Description } & $\mathbf{2 0 0 6}$ & $\mathbf{2 0 0 7}$ & $\mathbf{2 0 0 8}$ & $\mathbf{2 0 0 9}$ & $\mathbf{2 0 1 0}$ \\
\hline Gross Domestic Product (GDP)-in millions of & 3,120 & 3,400 & 3,757 & 3,917 & 4,119 \\
Euro & & & & & \\
GDP growth (annual \% based on constant & 4.0 & 5.0 & 5.4 & 4.0 & 4.6 \\
local currency) & 0.6 & 4.5 & 9.2 & -2.4 & 3.5 \\
Inflation, average consumer prices (annual \%) & & & & & \\
& 44.9 & 43.6 & 47.5 & 45.4 & 45.0 \\
Unemployment as \% of total labour force & 467.1 & 515.6 & 535.4 & 505.6 & 511.6 \\
Remittances in millions of Euros & 1,486 & 1,593 & 1,789 & 1,795 & - \\
Gross Domestic Product per capita in Euros & & & &
\end{tabular}

Source: Central Bank of Kosovo (Annual Report 2010), Ministry of Economy and Finance, and Statistical Office of Kosovo (GDP in Kosovo 2004-2009). 
The increased unemployment rates in Europe and in Northern America had contributed to the reduction of remittances from the Diaspora in Kosovo, which in 2009 decreased by $5.6 \%$, but in 2010 the Kosovar Diaspora remittances, recorded a slight increase compared to 2009 due to recovery of the economy. While remittances have contributed to the reduction of poverty, they had no significant role on the acceleration of the economic activity. In 2010, in the banking market of Kosovo operated eight commercial banks, six of which were with foreign capital and two of them with domestic capital. The Banks with foreign capital dominate the banking market in Kosovo and which managed $90.2 \%$ of total banking assets in $2010(91.1 \%$ in 2009). The remaining assets (9.8\% in December 2010) were managed by two locally owned banks (Central Bank of Kosovo, 2010). The performance of the banking system in Kosovo in 2009 was weaker than in 2008.Kosovo's banking system closed in 2009 with a net profit of 29.6 million Euros, which represented a profit of about $30.5 \%$ lower than in 2008 . It may be concluded that this reduction in profits, as seen above, is a result of the decline in lending, while spending followed a trend of growing at higher pace than revenues. This reduction of net profit had a negative effect on the main indicators of profitability of banking sector such as on the average return on assets (ROA) and average return on equity (ROE). While the ROA fell from 2.4 in 2008 to 1.4 in 2009 , the ROE fell from $24.7 \%$ in 2008 to $13 \%$ in 2009. The banking sector had revenues with amount of 201.5 million Euros during 2009 which was only $3.3 \%$ higher than the revenues in 2008, while this revenue growth in 2008 was about $24 \%$ compared to 2007 . The main reason for the decline in the revenues of the banking sector was the decrease in lending by this sector which then caused the decline in the revenue from interest on loans and as such had a negative effect on the total revenues. If in 2008 the annual growth of interest income was about $36.3 \%$, during 2009 the revenues from interest on loans would record an annual increase of only $13.9 \%$. Also, another important factor in the decline of the banking sector's revenues was the decline of the interest rate of EURIBOR European interbank market, which caused a sharp decline in revenues from placements in foreign commercial banks. These revenues in 2008 were 12.0 million Euros, while in 2009 they were only 2.8 million Euros. In general, the revenue structure of the banking sector is similar to previous years, and interest incomes are the main drivers of the banking sector revenues by participating with $81 \%$ in total revenues.

On the other hand, while the revenues fell, the expenses in 2009 in the banking sector grew at a higher pace than the revenues did but fortunately did not cause losses as the revenues were much higher. The expenses in 2009 rose by 17.7 $\%$ compared to 2008, reaching a value of about 171.3 million Euros. However, a positive factor in this regard is the fact that also in expenses there was observed a lower rate of growth compared to 2008, when expenses grew by an annual rate of growth of $26.3 \%$. This happened mainly because of the increase in general administrative expenses during 2009 by only $1.2 \%$, in contrast to 2008 when these expenses increased by about $23.4 \%$. 
Table 2. Income Statement of banking sector in Kosovo, in millions of Euro

\begin{tabular}{|c|c|c|c|c|}
\hline Description & 2006 & 2007 & 2008 & 2009 \\
\hline \multicolumn{5}{|l|}{ Revenues } \\
\hline Revenues from Interest & 88.8 & 117.9 & 155.7 & 163.2 \\
\hline Revenues from Non- Interest & 25.2 & 39.5 & 39.3 & 38.2 \\
\hline Total Revenues & 114 & 157.3 & 195 & 201.5 \\
\hline \multicolumn{5}{|l|}{ Expenses } \\
\hline Interest Expenses & 19.9 & 26 & 37.3 & 51.6 \\
\hline Other Expenses, except Interest & 19.6 & 19.9 & 21.9 & 32.6 \\
\hline General Administrative Expenses & 54.8 & 69.7 & 86 & 87 \\
\hline Total Expenses & 94 & 115.6 & 145 & 171.3 \\
\hline \multicolumn{5}{|l|}{ Net Revenues } \\
\hline Operating Net Revenues & 25.5 & 41.7 & 49 & 29.6 \\
\hline Net Revenues before Taxes & 26.6 & 41.3 & 47.6 & 28.9 \\
\hline Provisions for Taxes & 6.4 & 7.9 & 11.2 & 3.6 \\
\hline Net Profit/Losses of the period & 20.2 & 33.5 & 36.4 & 25.3 \\
\hline
\end{tabular}

Source: Central Bank of Kosovo, Annual Report 2010.

The category of general expenses and administrative expenses continue to represent about 50.6 $\%$ of total expenses, representing the largest category of expenditures, even though their participation in 2009 was 8.3 pp lower than last year. From the above table, it can be seen that the expenses for provisions on loans, which are part of the Non-Interest Expenses, reached a value of 25.7 million Euros in 2009 or in growth terms an increase of $51.3 \%$. This increase was caused by the growth of non-performing loan which increased from $3.3 \%$ in 2008 to $4.3 \%$ in 2009 . The participation on non-performing loans on total loans recorded even more increase in 2010. In 2010 the non-performing loans increased for $1.4 \mathrm{pp}$ (from $4.3 \%$ in 2009 to $5.8 \%$ in 2010), but even though the non-performing loans of the banking sector of Kosovo increased they remain to be the lowest compared to the courtiers of South East Europe (Central Bank of Kosovo, 2011).

In table number 3 is presented the percentage of nonperforming loans to total loans in some of European countries. 
Table 3. Bank Nonperforming Loans to Total Loans

\begin{tabular}{cccc}
\hline $\mathbf{0}$ & $\mathbf{2 0 0 6}$ & $\mathbf{2 0 0 7}$ & $\mathbf{2 0 0 8}$ \\
\hline Austria & 2,1 & 1,7 & $\ldots$ \\
Bulgaria & 2,2 & 2,1 & 2,4 \\
Czech Republic & 3,6 & 2,7 & 3,1 \\
Greece & 5,4 & 4,5 & 4,7 \\
Italy & 4,9 & 4,6 & $\ldots$ \\
Poland & 7,4 & 5,2 & 4,4 \\
Romania & 7,9 & 9,7 & 9,8 \\
Serbia & 4,1 & 3,8 & 5,3 \\
Hungary & 2,5 & 2,5 & 2,9 \\
\hline
\end{tabular}

Source: IMF

From the above mentioned data, it can be seen that in 2008 most of the countries presented in the table have reported a slight increase of non-performing loan to total loans. The highest increase was in Serbia where this ration increased from 3.8\% in 2007 to $5.3 \%$ in 2008 . From all the countries in the table, between 2006 and 2008 the highest increase of non-performing loans was in Rumania.

\section{THE EFFECTS OF THE GLOBAL FINAN- CIAL CRISIS}

The financial institutions operating in Kosovo, such as banks and microfinance institutions, base their operation mainly on local deposits and loans. As a result there is no much presence of the international financial markets which in one form or another was beneficial in isolating our country from its exposure to the recent financial crisis. Most of the banks use fixed interest rate, more specifically there is only one bank that offers interest rates using EURIBOR as the basic interest that may be affected from the behaviour of the international financial markets.

Secondly, the financial crisis may have had an effect on remittances sent to Kosovo from the emi- grants working and operating in the Diaspora. The money sent from abroad countries to Kosovo, for many families serve the only source of income as the unemployment rate in Kosovo is high up to $45 \%$ in 2010 according to the Statistical Office in Kosovo. As a result of financial crisis the remittances decreased because some of the Kosovar employees working abroad lost their jobs as big corporations reduced the number of workers in order to reduce the costs to survive the crisis. Specifically, the increase in the unemployment rate in Europe and North America has contributed to the reduction of remittances from the Diaspora in Kosovo, which in 2009 decreased by $5.6 \%$ compared to 2008 .

Thirdly, Kosovo faced also a negative effect in the FDIs, because many strong economy fear to enter in investments during the recession phase which was due to the financial crisis. During the recent years, the highest level of FDI in Kosovo was in 2007 when it reached up to 440 million Euros, followed by a slight decrease in 2008 and 2009, due to many domestic factors including the impact of global financial crisis. During the 2009 the FDI in Kosovo declined by $20 \%$, compared to 2008 . 
Overall, due to the decrease in the amount of lending, decrease of remittances and FDI, it can be suggested that the recent financial crisis did have an effect in the Economy of Kosovo but which was lower than in other countries. The Central Bank of Kosovo has taken all the reasonable steps to prevent the economy from the crisis. Capital index indicates capitalization for $17 \%$, the liquidity reserves are quite safe, there was an increase in assets by $30 \%$, with a slight increase also in profit. The Banks in Kosovo are quite dependent on local markets, they have more deposits than loans, which in this case is a positive indicator to prevent occurrence of the crisis in Kosovo. During 2009, the new banks entered in the banking market have increased the competition making the interest rates offered to the client to be somehow more favourable. However, all the financial institutions operating in Kosovo indicate that they are very careful in evaluating loan applicants, in order to ensure the highest probability on the returning capacity of the borrower. Despite the fears expressed by the banks for possible effects of financial crisis, during the year there has been a sustainable growth of new customers who are registered with their bank.

The main findings that can be made from the research are:

-The effects of the global financial crisis in Kosovo were very low,

-Kosovo's banking sector is secure and will not be affected from the global financial crisis because of low exposure to international financial markets,

-There is the possibility of decline of FDI and other donations and also of remittances.

It is imperative to use every lever available to try to solve the current problems but, however, banks must not lose sight of the need for innovation and development of all aspects of banking activity. This goal will be reached by the need of the credit institutions to improve efficiency and productivity. Operations must be streamlined, transactions' cost reduced as possible and the products and banking services rethought.

\section{CONCLUSIONS AND RECOMMENDA- TIONS}

It can be concluded that Kosovo as the least integrated region could manage to avoid the full impact of the global financial crisis on its economy. Research has suggested that the effects of the crisis have been particularly apparent in connection with the trade sector and remittances, where the crisis has mainly hit the exports of goods by making them lower. The crisis has affected the employment of emigrants living in the Diaspora which has direct negative impact on the remittances sent to Kosovo. Regarding the banking system, it is suggested that it has not been hit by the crisis, expressing the main effect of the significant decline in lending in comparison to the previous year.

The data for the GDP growth for 2009 is admirable as Kosovo recorded a growth rate of 3.8 $\%$ when most of neighbouring countries were in deep debt problems. However, it should be clarified that the main drivers of growth in Kosovo, which has helped in the alleviation of the crisis, has been the high level of public investment that has absorbed about $20 \%$ of the state budget. (EC, 2009, IMF 2009). This stimulation, which incidentally coincided with the offset of the crisis, helped the economy to considerably maintain a sustainable level of aggregate demand.

In fact, there have been two events that have offset the impact of the crisis in the case of Kosovo: there has been a low level of economic integration of Kosovo, and, there has been the definition of government priorities in terms of capital investment.

However, the policymakers in Kosovo should reassess the economic integration particularly in the future, because even though it proved to be a fortunate element in mitigating the crisis, the economic isolation is actually one of the main obstacles for further economic development of Kosovo. In the medium term, political steps should be concentrated to the direction of increasing the level of economic integration, which is shown as the determined for economic development in the ex - communist countries during the past two decades. 
However, the best answer to the economic crisis remains on the maintenance of macroeconomic stability - an increase of consumer price control, consolidation of public finances, aiming at the reduction of public debt in periods of economic growth, which would increase the scope for countercyclical budgetary policies in periods of economic downturn. Money and loans should follow a moderate growth, to the extent necessary to facilitate economic transactions and not be threat to the country's financial system.

The most fundamental and undeniable conclusion by all for the recent financial crisis is this: the high level of globalization of the economy, trades, or global finances favoured the rapid spread of crises in global level as well as its infection of almost all countries of the world.

To prevent the crisis the Central Bank of Kosovo has taken all the reasonable such as the capital index indicates capitalization for $17 \%$, maintaining safe the liquidity reserves, and increased the assets by $30 \%$, with a slight increase also in profit.

\section{REFERENCES}

Bitner, R. (2008).Confessions of a Subprime Lender, July 15, 2008.

Boissieu, S. (2008).Un an de crise des subprimes a cree une nouvelle donne financiere mondiale, inInvestir, 9 aount 2008. Central Bank of Kosovo. (2009a), Annual Report 2008, Prishtina, Kosovo.
Central Bank of Kosovo. (2009b), Annual Report 2009, Prishtina, Kosovo.

Central Bank of Kosovo. (2010), Annual Report 2010, Prishtina, Kosovo.

Central Bank of Kosovo. (2011), Financial Stability Report Number 2, December 2011, Pristina, Kosovo.

Cooper, G. (2008). The origin of financial crisis. Gaggi,M. (2009). From American crisis to world recession. Haderi, S. Papanagos, H. Sanfey, P. and Talka, M. (1999). Inflation and Stabilisation in Albania, Post - Communist Economies, Vol.1, No.1, p.127-141.

IMF, (2011), Crisis Management and Resolution: Early Lessons from the Financial Crisis.

IMF, (2009), World Bank Outlook, April 2009.

Paulson, (2007). Housing woes take bigger toll on economy than expected, AFP.

Romer, CH. (2003). Great Depression, UK.

Ruth, M. (2008). Home prices off record $18 \%$ in past year, Case - Shiller says, Economic Report, The Wall Street Journal.

Statistical Office of Kosovo, (2009), Gross Domestic Product in Kosovo 2004-2009.

Web-Sites used:

Central Bank of Kosovo, < http://www.bqk-kos.org/>,

European Bank for Reconstruction and Development, < http://www.ebrd.com/pages/research/economics/data.shtml>, European Commission, $<$ http://ec.europa.eu/index_en.htm>, International Monetary Fund, < http://fas.imf.org/>, Ministry of Labour and Social Welfare, $<$ http://mpms.rksgov.net/en-us/home.aspx>,

National Bank of Romani, < http://www.bnro.ro/Home. aspx>,

Statistical Office in Kosovo, < http://esk.rks-gov.net/eng/>, World Bank, < http://www.worldbank.org/>. 